\title{
Biological and Molecular Analyses of the Acibenzolar-S-Methyl- Induced Systemic Acquired Resistance in Flue-Cured Tobacco Against Tomato spotted wilt virus
}

\author{
B. Mandal, S. Mandal, A. S. Csinos, N. Martinez, A. K. Culbreath, and H. R. Pappu
}

First, second, third, fourth, and fifth authors: Department of Plant Pathology, University of Georgia, Coastal Plain Experiment Station, Tifton 31793; and sixth author: Department of Plant Pathology, P.O. Box 646430, Washington State University, Pullman 99164-6430.

Current address of first and second authors: Plant Virology Unit, Division of Plant Pathology, Indian Agricultural Research Institute, New Delhi 110012, India.

Current address of fourth author: Department of Plant Pathology, University of Kentucky, Lexington.

Accepted for publication 31 October 2007.

\begin{abstract}
Mandal, B., Mandal, S., Csinos, A. S., Martinez, N., Culbreath, A. K., and Pappu, H. R. 2008. Biological and molecular analyses of the acibenzolarS-methyl-induced systemic acquired resistance in flue-cured tobacco against Tomato spotted wilt virus. Phytopathology 98:196-204.

Tomato spotted wilt virus (TSWV) is an economically important virus of flue-cured tobacco. Activation of systemic acquired resistance (SAR) by acibenzolar-S-methyl (ASM) in flue-cured tobacco was studied under greenhouse conditions by challenge inoculation with a severe isolate of TSWV. ASM restricted virus replication and movement, and as a result reduced systemic infection. Activation of resistance was observed within 2 days after treatment with ASM and a high level of resistance was observed at 5 days onward. Expression of the pathogenesis-related (PR) protein gene, PR-3, and different classes of PR proteins such as PR-1,

PR-3, and PR-5 were detected at 2 days post-ASM treatment which inversely correlated with the reduction in the number of local lesions caused by TSWV. Tobacco plants treated with increased quantities of ASM $(0.25$, $0.5,1.0,2.0$, and $4.0 \mathrm{~g}$ a.i./7,000 plants) showed increased levels of SAR as indicated by the reduction of both local and systemic infections by TSWV. The highest level of resistance was at $4 \mathrm{~g}$ a.i., but this rate of ASM also caused phytotoxicity resulting in temporary foliar spotting and stunting of plants. An inverse correlation between the TSWV reduction and phytotoxicity was observed with the increase of ASM concentration. ASM at the rate of 1 to $2 \mathrm{~g}$ a.i./7,000 plants activated a high level of resistance and minimized the phytotoxicity. Use of gibberellic acid in combination with ASM reduced the stunting caused by ASM. Present findings together with previous field experiments demonstrate that ASM is a potential option for management of TSWV in flue-cured tobacco.
\end{abstract}

Systemic acquired resistance (SAR) is a broad-spectrum defense system present in plants, which was realized as early as $1901(5,11,64)$, and was first demonstrated against a virus by Ross (66) in tobacco against Tobacco mosaic virus (TMV). Subsequent studies showed the SAR response to be long lasting and effective against diverse pathogens such as bacteria, fungi, nematodes, and parasitic plants, and was considered a potential tool for crop protection $(18,24,31,32,41,56,75)$. Activation of SAR is associated with a series of signal transduction events and the expression of the SAR gene family $(24,69,76,77)$. The SAR genes encode various pathogenesis-related (PR) proteins, which play an active role in the resistance process against fungal pathogens $(2,39,40)$.

Several synthetic chemicals such as $\beta$-aminobutaric acid, isonicotinic acid, benzol [1,2,3] thiadiazol-7-carbothioic acid-Smethyl ester (BTH), acibenzolar-S-methyl (ASM, a derivative of BTH), salicylic acid (SA), and phosphates have been shown to be activators of SAR response in a variety of crop-pathogen systems $(7,13,18,20,23,31,33,42,49,56,67,68,72,73,75)$. Of all these chemicals, only ASM was commercialized as an activator for disease resistance in plants. ASM was discovered in 1989 by Ciba Geigy (Novartis) (20). It was classified and registered as a 'reduced risk

Corresponding author: H. R. Pappu; E-mail address: hrp@wsu.edu

* The $e$-Xtra logo stands for "electronic extra" and indicates that Figures 4 and 6 appear in color online.

doi:10.1094/PHYTO-98-2-0196

(c) 2008 The American Phytopathological Society compound' in 1998 in the United States (73) and marketed under the trade name Actigard in the United States (55) (Syngenta Crop Protection Inc., Greensboro, NC) and BION in Europe (Syngenta Ltd., Basel, Switzerland). ASM activates the same defense responses as the natural signal molecule SA does in the biological activation of SAR (69). ASM/BTH was shown to activate antifungal and antibacterial activity in several monocot and dicot crop species $(1,4,6,8-10,14,15,21,22,25,28,29,37,38,44,45,51,61,65)$. BTH was shown to activate SAR response against viruses such as TMV in tobacco (20), Turnip crinkle virus (TCV) in Arabidopsis (36), and Cucumber mosaic virus (CMV) in tomato (3).

Tomato spotted wilt virus (TSWV), a member of the genus Tospovirus and family Bunyaviridae (19), is one of the most widely occurring and economically important plant viruses $(53,54$, $58,62,71)$. TSWV is transmitted by several species of thrips $(74,80)$. TSWV is a serious threat to many important crops such as peanut, pepper, flue-cured tobacco, and tomato in the southern United States. In flue-cured tobacco, TSWV causes spotted wilt disease characterized by localized and systemic necrosis and stunting symptoms $(17,43)$. In Georgia, flue-cured tobacco is seriously affected by TSWV causing stand loss in excess of $30 \%$ with an estimated loss of more than $\$ 17$ million in 2004 (60). Control of TSWV in flue-cured tobacco by insecticides and cultural practices was found unsatisfactory $(46,47)$. Resistant cultivars were considered to be the most effective approach for managing TSWV (12). However, no source of resistance against TSWV is available in flue-cured tobacco. Moreover, resistance breaking strains of TSWV were reported $(26,27,35,52)$ which were likely due to genome reassortment (63) making breeding for 
durable TSWV resistance more challenging. The genetic diversity of TSWV isolates from flue-cured tobacco was documented (57). Abundance of thrips vectors, wide range of alternate sources of infection, and lack of host resistance make it difficult to control TSWV in flue-cured tobacco. It was shown that the treatment of flue-cured tobacco (cv. K-326) with ASM resulted in significant reduction of final incidence of spotted wilt disease (16,59). Both studies suggested that ASM alone or in combination with imidacloprid is an effective tool for management of spotted wilt in fluecured tobacco. ASM was also shown to reduce the incidence of spotted wilt disease caused by TSWV in field-grown tomato (50) and mosaic disease caused by TMV in flue-cured tobacco (48). Although, ASM was shown to reduce spotted wilt disease in fluecured tobacco under field conditions, the relation between ASM rate of application and development of TSWV infection, time of activation of resistance, and the mechanism of action have not been studied. We report the results of a comprehensive study on the biological and biochemical aspects of ASM-induced SAR in tobacco against a severe isolate of TSWV.

\section{MATERIALS AND METHODS}

Source of inoculum. A lettuce isolate of TSWV (GAL), collected from Colquitt County, Georgia, causing severe necrosis and mortality in flue-cured tobacco seedlings, cv. K326, was used in this study (43). The isolate was maintained on cv. K326 in the greenhouse. Fresh leaves with systemic symptoms of TSWV were harvested at 15 days postinoculation (DPI) and were used as the source of inoculum.

Plant materials. In the greenhouse, tobacco seeds of cv. K326 were sown in seed pans containing soil mix consisting of Canadian sphagnum peat moss ( 75 to $85 \%$ ), perlite (15 to $20 \%$ ), and vermiculite 5 to $10 \%$ (Berger Peat Moss-Lee Berger Itee, SaintModeste, Quebec, Canada). Twenty five to thirty days after seeding (DAS), seedlings were transplanted in Styrofoam flats (Speedling Inc., Sun City, FL) with $6.45 \mathrm{~cm}^{2}$ cell. Eight to ten days after first transplanting, seedlings were again transplanted to a nine-cell flat floating on water or to pots (24.5-cm diameter).

ASM treatment. Plants of K326 at 40 to 45 DAS were sprayed with water followed by ASM (as 50\% active ingredient [a.i.] in wettable powder formulation) dissolved in water (16). Applications were made with a backpack $\mathrm{CO}_{2}$ powered sprayer fitted with three TX-12 tips and pressurized to $310 \mathrm{kPa}$. To evaluate the effect of various concentrations of ASM on TSWV infection, plants were treated with ASM at the rates of 0, 0.25, 0.5, 1.0, 2.0, and $4.0 \mathrm{~g}$ a.i./7,000 plants. Imidacloprid (Imidacloprid 2F, Bayer Crop Science, Research Triangle Park, NC) was sprayed at the rate of $9.94 \mathrm{~g}$ a.i/1,000 plants (16,59). After the application of ASM, the plants were washed by spraying with $80 \mathrm{ml}$ of water per flat containing nine plants, to move the ASM into the root zone. To determine the time required for SAR activation, plants were treated with two concentrations of ASM ( 2 and $4 \mathrm{~g}$ a.i. of ASM/7,000 plants) as described above. To determine the effect of age of tobacco plants on SAR activation, seedlings (47 DAS) and older plants (77 DAS) were treated with $2 \mathrm{~g}$ a.i./7,000 plants. For analyzing the PR gene expression, plants were treated with only $2 \mathrm{~g}$ a.i. of ASM/7,000 plants. The nontreated control plants were sprayed with distilled water only. Each experiment was repeated at least twice.

Gibberellic acid (GA3) treatment. The effect of GA3 (Sigma Chemical Company, St. Louis, MO) was evaluated to determine its effect in reducing the stunting caused by ASM treatment. GA3 at the rate of $50 \mu \mathrm{g} /$ plant was used alone and in combination with ASM (2 g a.i./7,000 plants). Plants were treated with GA3 first and then after a few hours ASM was applied. This treatment was compared with ASM alone, GA3 alone, GA3+ASM, and nontreated control and included six replicates. Nine plants (45 DAS) in a Styrofoam flat were used for each replicate in each treatment.
Challenge inoculation. ASM-treated plants were challenged by mechanical inoculation with TSWV. Inoculum was prepared by grinding systemically infected leaves in $0.1 \mathrm{M}$ phosphate buffer, pH 7.0, containing $0.2 \% \mathrm{Na}_{2} \mathrm{SO}_{3}$ and $0.01 \mathrm{M}$ mercaptoethanol at the rate of 1:10 tissue and buffer ratio (wt/vol). Debris was removed by squeezing the extract through a layer of nonabsorbent cotton. To this extract, 2\% Carborundum 320 grit and 1\% Celite 545 (Fisher Scientific, Fair Lawn, NJ) were added. Inoculum was maintained on ice and applied to the two youngest, fully expanded leaves of each seedling by gently rubbing with a cotton swab dipped in the inoculum. Inoculations were done in the greenhouse after sunset at 25 to $30^{\circ} \mathrm{C}$. After inoculation, plants were lightly misted with water.

Plants were inoculated 7 to 8 days posttreatment (DPT) except in the experiment to determine the time of SAR activation, where inoculation was done at 1-day intervals until 7 DPT.

Assessment of TSWV infection, phytotoxicity, and statistical analysis. After inoculation, plants were inspected daily for symptom development. The number of local lesions that developed on the two inoculated leaves of each plant was counted at 6 DPI. Local infection was confirmed by testing a portion of inoculated leaves (200 mg from each plant) by enzyme-linked immunosorbent assay (ELISA). ELISA was performed with a commercially available kit (Agdia Inc., Elkhart, IN). ELISA was conducted in 10-fold serial dilution of the sap to determine the relative levels of TSWV in the inoculated leaves of plants treated with ASM. Two samples from each treatment showing the highest and the lowest ELISA values in the previous test for examination of local infection were selected for the dilution tests. From the four trials, a total of eight plants for each concentration of ASM treatment was analyzed by ELISA. Plants were allowed to grow for a longer period of time after evaluation of local infection to study the development of systemic symptoms. Appearance of systemic symptoms was determined. The presence of TSWV was determined in roots and newly emerged leaves by ELISA. The number of leaf spots developed due to ASM treatment was counted on the treated leaves at 14 DPT. Plant height was measured from the base of the plant to the longest tip of leaf. Root length was measured carefully pulling out of the plant from the cell of the flat.

Data on local lesions, percent plants locally and systemically infected, relative levels of TSWV, and phytotoxicity were analyzed by SAS (SAS version 5, SAS Institute, Cary, NC). The local lesion data at varying concentrations of ASM were fit to the nonlinear regression model: $a \times e(-b x$ rate). To analyze the effect of ASM on the local and systemic infection, multiple regression analysis was based on the following model: $y=I+a X+b X^{2}$, where regression coefficients are $I=105.3, a=-34.6$, and $b=$ 2.77. The association between ELISA absorbance values and ASM rate was quantified by polynomial regression (imidacloprid treatment was excluded). The model used was $y=a+b A_{L}+c A_{Q}+$ $d T_{L}+e T_{Q}+f A_{L} T_{L}+g A_{L} T_{Q}+h A_{Q} T_{L}+i A_{Q} T_{Q}+e$, where y $=$ measured data, $a=$ intercept, $b-i=$ coefficient determined during regression, $A_{L}=$ the linear effect of $\log _{e} \mathrm{ASM}$ rate, $A_{Q}=$ the quadratic effect of $\log _{e} \mathrm{ASM}$ rate, $T_{L}=$ the linear effect of $\log _{10}$ dilution level, $T_{Q}=$ the quadratic effect of $\log _{10}$ dilution level, $A_{L} T_{L}$, $A_{L} T_{Q}, A_{Q} T_{L}, A_{Q} T_{Q}=$ interaction, and $e=$ unexplained error.

Local lesion data were subjected to analysis of variance in SAS. The experiment had a factorial design with ASM treatments and inoculation as factors. Time was fitted to a quadratic equation to relate number of lesions to DPT of ASM. A sampling unit consisted of the mean number of lesions per leaf calculated from eight plants evaluated separately.

Assay of mRNA of PR protein induced. Five leaves were collected from each treated and nontreated plant and pooled for total RNA extraction. The ASM-treated samples included were (i) treated leaves showing spots from phytotoxicity and (ii) top young leaves that emerged after ASM treatment from the same 
plant as in sample 1, which were not showing any phytotoxic symptoms. The nontreated control samples included were from lower and upper leaves with the corresponding position as in case of the treated plants. Nontreated cowpea (Vigna unguculata) leaf tissues were included as a non-tobacco control. Total RNA was isolated using RNeasy Mini Kit (Qiagen Inc., Valencia, CA) according to manufacturer's instructions. From the total RNA, mRNA was purified by the Oligotex mRNA Kit (Qiagen Inc.). Equal amount of total mRNA (800 ng) for each sample was electrophoresed in a formaldehyde agarose gel following the protocol described by the manufacturer. The gel was blotted to a nylon membrane by the capillary transfer method (70). Biotinylated DNA probe to PR-Q gene was prepared by random priming method using north2South Biotin Random Prime Kit (Pierce, Rockford, IL). PR-Q clone was obtained from L. Friedrich (Novartis). The mRNA blot was hybridized with the nonradioactive probe to PR-Q DNA using North2South Chemiluminescent Nucleic Acid Hybridization and Detection Kit (Pierce).

Protein extraction and western blot assay for PR proteins. Five plants treated with ASM or water were collected daily until 10 DPT. On each day, $1.5 \mathrm{~g}$ of leaf sample was collected from five plants and stored at $-80^{\circ} \mathrm{C}$. The nontreated sample was collected from the water-treated plants and was collected until 3 DPT, and then was pooled as one sample. Total protein was extracted from treated or nontreated samples following the methods described by Jung et al. (30) and Ziadi et al. (81). Briefly, frozen leaf material of $1.5 \mathrm{~g}$ was ground in $2.5 \mathrm{ml}$ of $0.5 \mathrm{M}$ sodium acetate buffer, $\mathrm{pH}$ 5.2, containing $15 \mathrm{mM}$ 2-mercaptoethanol. The extract was centrifuged at $15,000 \times g$ for $15 \mathrm{~min}$, and the supernatant was desalted by dialyzing for 18 to $20 \mathrm{~h}$ with three changes of $0.05 \mathrm{M}$ sodium acetate buffer, $\mathrm{pH} 5.2$.

Total protein content in the supernatant of the each sample was determined in six replicates by using the Bio-Rad Protein Assay Kit II with bovine serum albumin as standard (Bio-Rad Laboratories, Hercules, CA). Sodium dodecyl sulfate-polyacrylamide gel electrophoresis (SDS-PAGE) was done as previously described $(30,34)$. To visualize the protein bands induced by ASM, the gel was stained with Coomassie blue. To detect PR proteins, western blot assays were performed using antisera to tobacco $P R$ proteins PR-1(C), PR-2(2), PR-3(Q), PR-5(S), PR-6(basic), and PR8(acidic) (antisera were provided by B. Fritig, Institute de Biologie Moleculaire des Plantes, Strassbourgh, France).

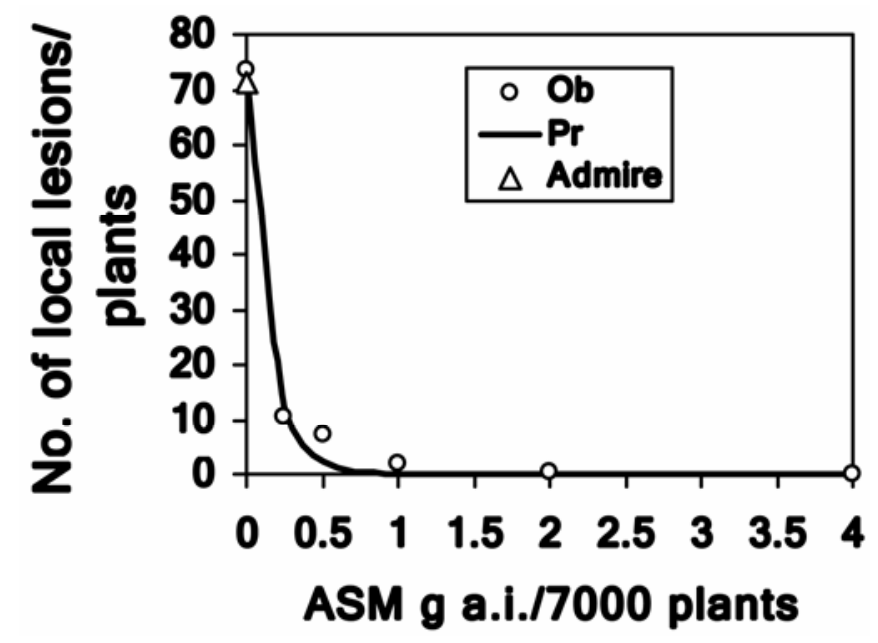

Fig. 1. Relationship of quantity of acibenzolar-S-methyl (ASM) used to treat tobacco plants of cv. K326 and the development of number of local lesions caused by Tomato spotted wilt virus. Plants were treated with ASM at the rate of $0,0.25,0.5,1.0,2.0$, and $4.0 \mathrm{~g} / 7,000$ plants or imidacloprid at the rate of $39.78 \mathrm{~g} / 1,000$ plants. Local lesions were counted at 6 days postinoculation. $\mathrm{Ob}=$ observed; $\mathrm{Pr}=$ predicted.

\section{RESULTS}

Effect of ASM on local infection. Local lesions were observed on the inoculated leaves at 3 DPI and appeared as chlorotic rings, and by 5 DPI the lesions became necrotic. The lesions had the characteristic brown margin with a blighted center. Mechanically inoculated plants produced an average of 73.6 lesions per plant on the nontreated plants. Leaves wilted and eventually withered. At $0.25 \mathrm{~g}$ a.i. of ASM, only 10.6 lesions per plant developed, which was a significant reduction compared with that in the nontreated control. The mean number of local lesions declined further to 1.8 to 0.2 at 1 to $4 \mathrm{~g}$ a.i. of ASM (Fig. 1). The majority of the plants were free from local lesions when treated with $\geq 2 \mathrm{~g}$ a.i. of ASM. Plants treated with imidacloprid had a similar number of local lesions compared with nontreated plants. The proportions of plants with local symptoms were 96.7 and $84.4 \%$ at 0.25 and $0.5 \mathrm{~g}$ a.i. of ASM/7,000 plants, respectively (Fig. 2A). These two concentrations did not have any significant role in reducing the local symptoms compared with the nontreated plants. Treatment with $\geq 2 \mathrm{~g}$ a.i. of ASM reduced by 6.2 to $18.7 \%$ of plants with local symptoms (Fig. 2A). TSWV was detected in 63 to $99.7 \%$ of the inoculated leaves among plants treated with 0.25 to $4 \mathrm{~g}$ of ASM/7,000 plants. All plants treated with imidacloprid showed local lesions and infection by TSWV that was confirmed by ELISA.

Effect of ASM on systemic infection. When the locally infected plants were allowed to grow, systemic symptoms began developing from 6 to 10 DPI onwards. Local infection took place in all the inoculated plants by 3 to 5 DPI but systemic infection resulted in only $18.3 \%$ of plants by 30 DPI. In the ASM-treated plants, the percent symptomatic plants was reduced from 7.8 to $0.3 \%$ as the concentrations of ASM treatment were increased from 0.25 to $4 \mathrm{~g}$ a.i./7,000 plants (Fig. 2B) and ELISA-positive plants were reduced from 12.5 to $0.2 \%$. At $\geq 1 \mathrm{~g}$ of ASM, plants were free from systemic symptoms. Imidacloprid treatment did not result in reduction in systemically infected plants compared with nontreated plants.

Effect of ASM on the level of viral antigen. The ELISA readings for nontreated plants and imidacloprid-treated plants were 1.4 and 1.2, respectively, at $10^{-1}$ dilution of sap (Fig. 3). The dilution end point of the viral antigen in these groups of plants was $10^{-4}$. In the ASM-treated plants, the dilution end points of the viral antigen were $10^{-4}$ at $0.25 \mathrm{~g}$ a.i., $10^{-3}$ at 0.5 to $2 \mathrm{~g}$ a.i., and $10^{-2}$ at $4 \mathrm{~g}$ a.i. The highest absorbance values were obtained with the lowest rate of ASM, and as the rate increased the absorbance values decreased in the treated plants. Analysis of the absorbance values at 10 -fold serial dilutions showed that the ASM treatment significantly reduced the level of TSWV in flue-cured tobacco plants (Fig. 3).

Phytotoxicity caused by ASM. Minute white necrotic lesions developed on the ASM-treated leaves but not on the imidaclopridor water-treated leaves. The lesions the were caused due to ASMinduced phytotoxicity and those produced by TSWV were distinguishable by the absence of a brown necrotic zone around the blighted center of the phytotoxic lesions (Fig. 4B, which was present in the lesions caused by TSWV (Fig. 4A). The lesions per plant increased with ASM concentrations. Significantly more lesions (100/plant) developed in the ASM-treated plants at the rate of $\geq 1 \mathrm{~g}$ a.i./7,000 plants. The spots were not seen in the successive leaves that emerged after the ASM treatment. ASM treatment affected the height of the plants (Table 1). At $0.25 \mathrm{~g}$ of ASM, plant height was significantly higher than in control plants. At $\geq 1 \mathrm{~g}$ of ASM, a significant reduction of plant height was observed. The stunting caused by ASM was overcome by treating plants with ASM and GA3 (50 $\mu \mathrm{g} / \mathrm{plant})$. Root length, however, was not influenced by the ASM treatment (Table 1).

Time required for resistance activation. The numbers of local lesions in the ASM-treated and nontreated plants developed over 
the time posttreatment are presented in Figure 5. One day after treatment with $4 \mathrm{~g}$ of ASM, 88.8 and 99 lesions developed per plant treated with ASM or water, respectively. At 2 DPT onward, there was a decline in the number of local lesions relative to control. At 5 days onward, plants produced a few lesions (Fig. 6) compared with the nontreated (87.3 to 77.1 lesions/plant) plants. Similarly, plants treated with $2 \mathrm{~g}$ of ASM also showed a declining trend in the number of lesions with the increase of time of treatment. At 5 DPT, plants treated with both dosages ( 2 or $4 \mathrm{~g}$ a.i.) showed fewer local lesions (4.3 at $4 \mathrm{~g}$ a.i and 8.1 at $2 \mathrm{~g}$ a.i.) compared with the nontreated (71.6 at $4 \mathrm{~g}$ a.i and 77.3 at $2 \mathrm{~g}$ a.i) plants.

A

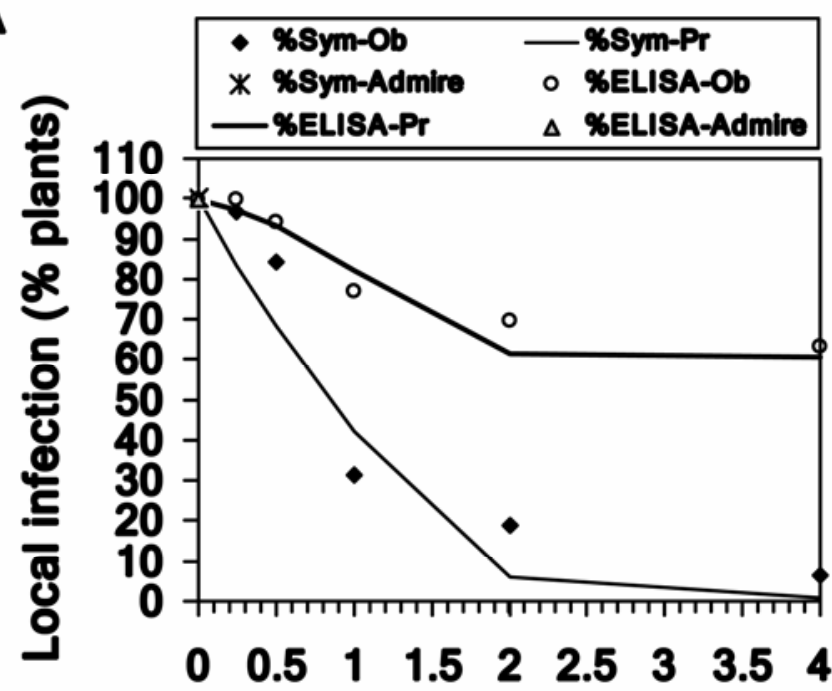

ASM g a.i.i./7000 plants

B

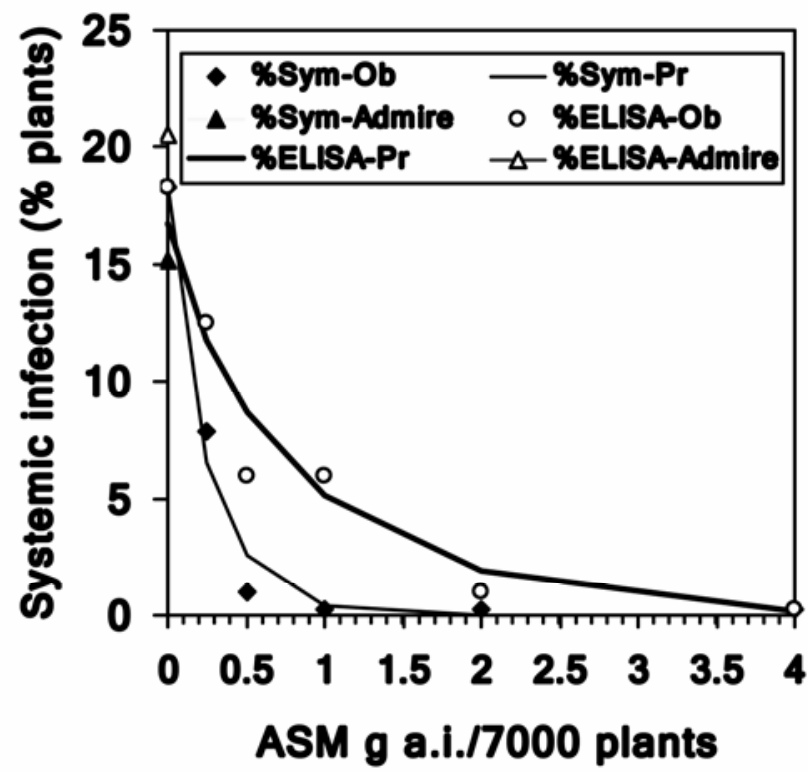

Fig. 2. Effect of concentration of acibenzolar-S-methyl (ASM) on infection of tobacco cv. K326 with Tomato spotted wilt virus (TSWV). A, Local infection and $\mathbf{B}$, systemic infection. Plants were treated with ASM at the rate of $0,0.25$, $0.5,1.0,2.0$, and $4.0 \mathrm{~g}$ a.i./7,000 plants or imidacloprid at the rate of $39.68 \mathrm{~g} /$ 1,000 plants. Infection was judged by presence of symptoms and enzymelinked immunosorbent assay (ELISA) following mechanical inoculation of TSWV. Sym = symptomatic plants; ELISA = ELISA-positive plants; $\mathrm{Ob}=$ observed; $\operatorname{Pr}=$ predicted.
Effect of age of plants on the activation of resistance. Inoculation of TSWV in the nontreated seedling plants resulted in 87.6 lesions per plant at 47 DAS (Table 2). All plants were locally infected and $73.3 \%$ became systemically infected as determined by ELISA. In ASM-treated seedlings, $60 \%$ of the plants were locally infected (10\% symptomatic) and $6.7 \%$ of the plants were systemically infected (3.3\% had systemic symptoms). In older plants (77 DAS), there were 20.3 and 3.1 local lesions/plant, 100 and $90 \%$ of plants with localized infection and 13.3 and $6.7 \%$ of plants with systemic infection in the nontreated and ASM-treated plants, respectively. The differences of these responses between the treated and nontreated older plants were statistically significant (Table 2). In the older plants, $100 \%$ of the nontreated and $63.30 \%$ of the treated plants showed local symptoms, although, none of these plants produced systemic symptoms.

Effect ASM on tobacco cultivars for resistance activation. Tobacco cvs. K326, NY21, NC71, NC72, NC297, NC2326, Cu748, and $\mathrm{Cu} 752$ treated with ASM showed significant reductions in number of local lesions per plant as well as incidence of systemic infection compared with the nontreated control plants (data not shown). High-level resistance was observed to be activated by ASM in cvs. NC71, NC72, NC297, and NC2326 as none of the plants were systemically infected.

Induction of PR gene and protein expression. The PR-Q gene's transcript was detected in leaves treated with ASM and in the younger leaves developed after the ASM treatment (Fig. 7A). In the nontreated tobacco and cowpea plants, accumulation of PRQ mRNA was not detected.

SDS-PAGE gel showed higher levels of certain proteins in the ASM-treated plants compared with the nontreated plants. The most prominent protein band was seen at molecular weight (MW) of 36,000, although this band was also present in the nontreated plants. In the ASM-treated plants there were three protein bands ranging from MW of 46,000 to 45,000. An additional eight protein bands ranging between MW of 14,000 to 36,000 also were observed. Proteins of MW 29,000 and smaller may represent PR3 and PR-5 and the 21,000 Da protein may represent PR-1. The quantity of the total proteins increased by 2.7 to 4 times in the ASM-treated samples compared with the nontreated plants over the period of time after the ASM treatment. Western blotting (Fig. 7B) with antibody raised against PR-1 showed mild accumulation of PR-1 a day after treatment with ASM. An increased amount of

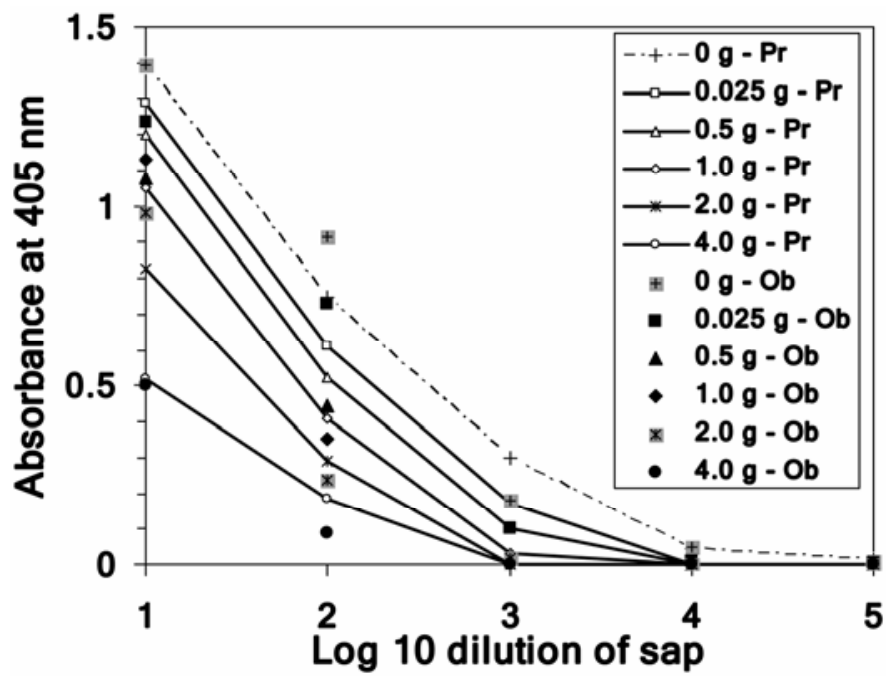

Fig. 3. Effect of different dosage of acibenzolar-S-methyl (ASM) on the relative levels of Tomato spotted wilt virus. Seedlings of tobacco cv. K326 were treated with $0,0.25,0.5,1.0,2.0$, and $4.0 \mathrm{~g}$ of ASM/7,000 plants or imidacloprid at the rate of $39.7 \mathrm{~g} / 1,000$ plants. Regression lines representing ASM treatment are significantly different $(P<0.05) . \mathrm{Pr}=$ predicted, $\mathrm{Ob}=$ observed. 

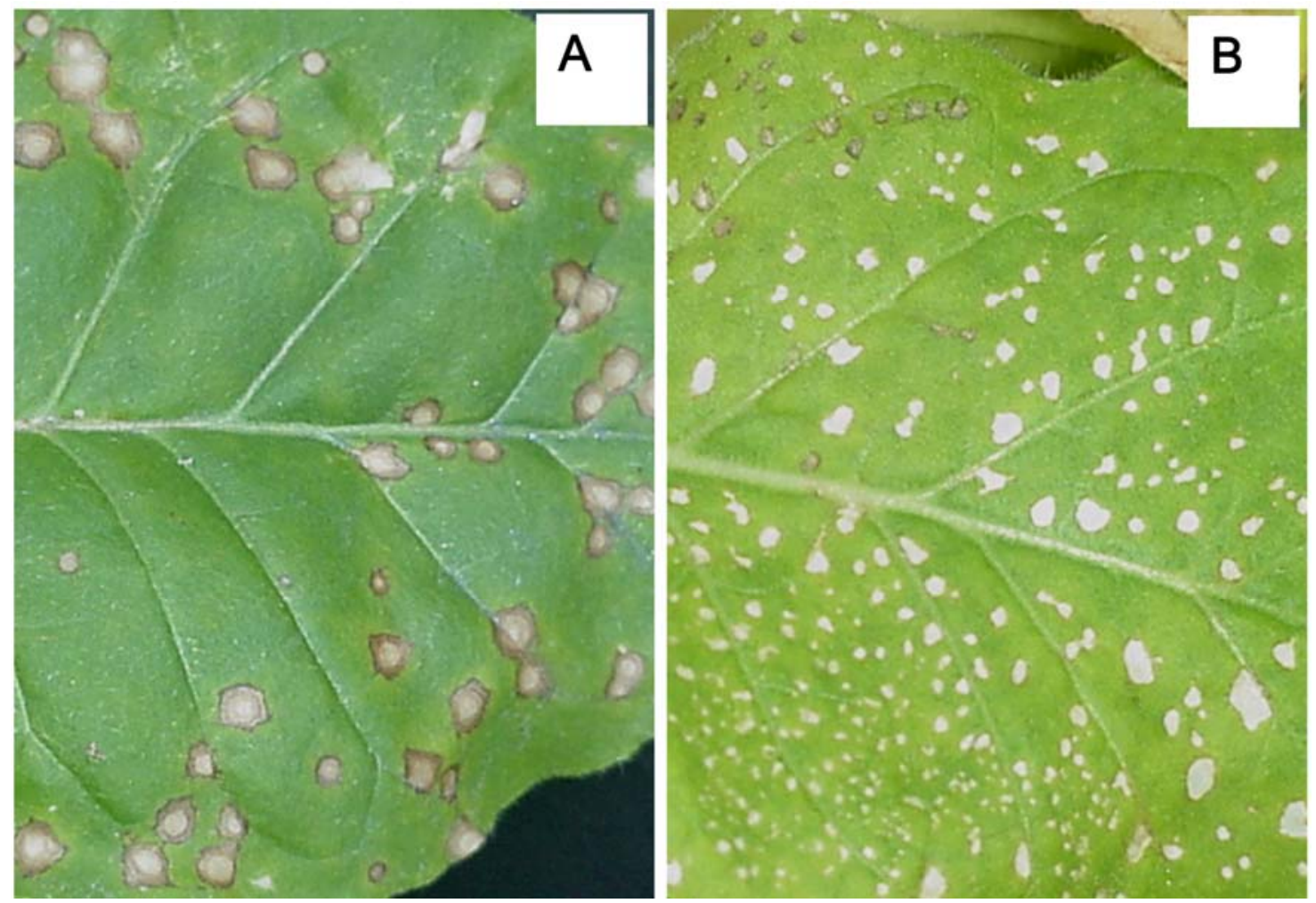

Fig. 4. Lesions caused by A, Tomato spotted wilt virus and B, phytotoxic leaf spots due to application of acibenzolar-S-methyl (4 g a.i./7,000 plants) developed in tobacco cv. K326.

TABLE 1. Root length and plant height of flue-cured tobacco cv. K326 in response to different concentrations of acibenzolar-S-methyl ${ }^{\mathrm{z}}$

\begin{tabular}{lcc}
\hline ASM g a.i./7,000 plants & Root length $(\mathrm{cm})$ & Plant height $(\mathrm{cm})$ \\
\hline Imidacloprid & $23.7 \mathrm{a}$ & $32.8 \mathrm{a}$ \\
0 & $24.3 \mathrm{a}$ & $33.1 \mathrm{a}$ \\
0.25 & $23.6 \mathrm{a}$ & $36.6 \mathrm{~b}$ \\
0.5 & $23.9 \mathrm{a}$ & $34.7 \mathrm{a}$ \\
1.0 & $23.8 \mathrm{a}$ & $31.2 \mathrm{c}$ \\
2.0 & $24.6 \mathrm{a}$ & $27.1 \mathrm{~d}$ \\
4.0 & $23.3 \mathrm{a}$ & $26.6 \mathrm{~d}$ \\
\hline
\end{tabular}

${ }^{\mathrm{z}}$ Root length and plant height were measured 60 days posttreatment. Values in columns marked with same letter are not significantly different at $P=0.05$ (least significant differences for root length and plant height were 5.5 and 1.6, respectively). Concentration of imidacloprid was $39.68 \mathrm{~g}$ a.i./7,000 plants.

PR-1 was observed from 2 days onward. PR-3 and PR-5 were also accumulated at 2 days onward after treatment with ASM. No accumulation of PR-2, PR-6, and PR-8 were observed in the ASM-treated plants (not shown).

\section{DISCUSSION}

The present study demonstrates that treatment of flue-cured tobacco with ASM activates high levels of resistance against a severe isolate of TSWV and the activation of resistance is correlated with the coordinated expression of PR proteins following treatment with ASM.

Previous studies showed that the field experiments with foliar sprays of ASM provided protection in flue-cured tobacco against spotted wilt disease $(16,59)$. The appropriate quantity of ASM required for activation of resistance was not known and thus a higher dosage of ASM (8.4 to $67.3 \mathrm{~g}$ a.i/7,000 plants) was used $(16,59)$. In this study, we utilized uniform environmental conditions and mechanical inoculation to ensure a high rate of infection which facilitated a detailed examination of the interaction of
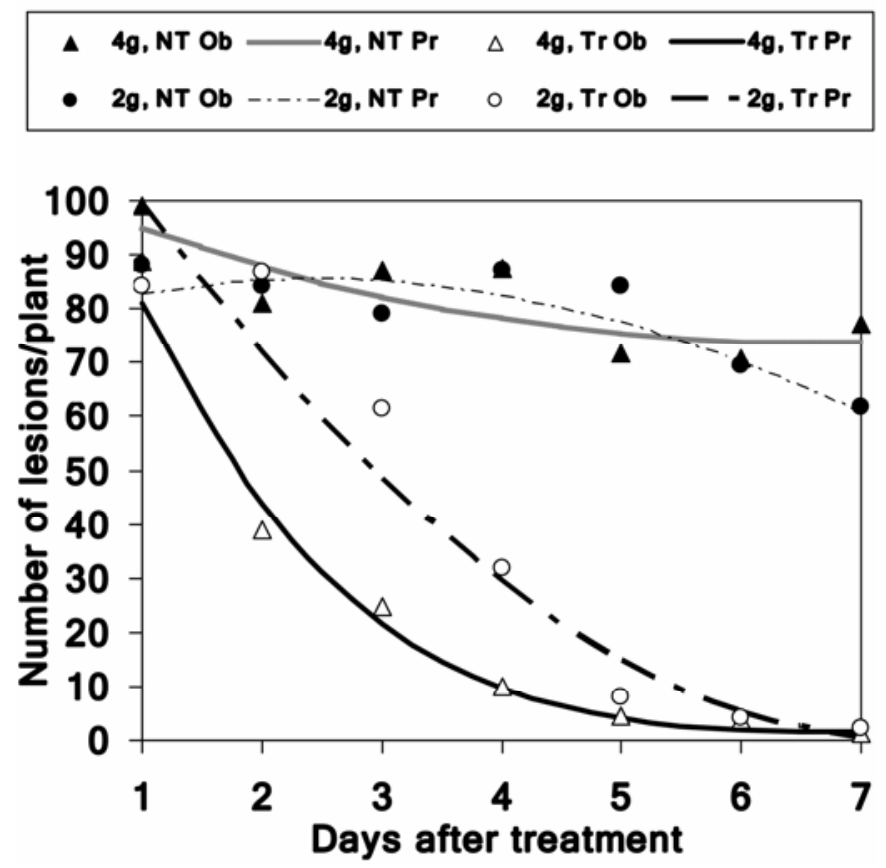

Fig. 5. Number of local lesions that developed on seedlings of tobacco cv. K326 treated with 2 or $4 \mathrm{~g}$ of acibenzolar-S-methyl/7,000 plants followed by inoculation with Tomato spotted wilt virus at 1-day interval until 7 days posttreatment. Number of lesions was counted at 6 days postinoculation. $\mathrm{NT}=$ nontreated; $\mathrm{Ob}=$ observed; $\mathrm{Pr}=$ predicted.

TSWV and tobacco under the ASM-induced SAR. As the dosage of ASM increased from 0.25 to $4 \mathrm{~g}$ a.i/7,000 plants, the number of local lesions, incidence of plants showing local and systemic infection, and the relative levels of TSWV in the treated plants decreased. At $4 \mathrm{~g}$ of ASM, the highest level of disease resistance was observed compared with the other lower dosage. But at this 
dose plants showed the highest level of phytotoxic symptoms such as white necrotic lesions on the treated leaves and overall stunting of plants. The phytotoxicity increased with the increase of ASM dosage. However, the lesions associated with phytotoxicity do not persist in the new growth of foliage. Field experiments with ASM showed reduction of growth in flue-cured tobacco $(16,48,59)$. Csinos et al. (16) conducted greenhouse experiments to determine the effect of ASM dosage on tobacco growth and found varying levels of growth reduction at 21 DPT. In the present study, when ASM-treated plants were allowed to grow for a longer period of time (60 days after transplanting) significant reductions in plant height were observed at rates of 1 to $4 \mathrm{~g}$ of ASM. Although ASM suppressed TSWV, stunting caused by ASM could be an issue. Use of ASM with GA3 showed compensation of the ASM-induced stunting. There was a dose-dependent response of ASM on anti-TSWV activity and phytotoxicity. The higher the rate, the greater the reduction of TSWV and more phytotoxicity. Therefore, it was necessary to find a compromise between an effective dose for suppressing TSWV and minimizing the phytotoxicity. A dose between 1 to $2 \mathrm{~g}$ of ASM showed significant disease suppression and less phytotoxicity. A dosedependent SAR activation by ASM was shown against downy mildew pathogen (81).

ELISA revealed the presence of symptomless infections. In the field situation a similar situation was observed $(16,59)$. Thus, ASM appears to suppress symptoms rather than prevent plants from getting infected. However, in the present study, analysis of ELISA absorbance values showed reduction of relative virus levels in ASM-treated plants suggesting a possible suppressive effect of ASM on virus replication. Reduction of CMV-Y was observed in BTH-treated tomato plants (3) and TCV was not detected in Arabidopsis plants treated with BTH (36).

Yield losses caused by TSWV in tobacco are due to the development of systemic symptoms. Under field conditions, local symptoms were often observed without adverse effects on plants if systemic symptoms fail to develop (A. S. Csinos, unpublished data). In the present study, local infection of TSWV was found in a higher percentage (63.0 to $99.8 \%$ based on the quantities of ASM) compared with those that developed systemic infection (0.3 to $12.5 \%)$. This suggests that ASM is potentially restricting TSWV movement to the site of inoculation while it cannot be ruled out that there are other factors that influence the development of systemic infection of TSWV in flue-cured tobacco.

In field trials, repeated application of ASM a month after transplanting did not reduce TSWV incidence, although ASM treatment of plants prior to transplanting showed reduction in TSWV incidence (16). This observation led us to examine the role of plant age in response to ASM treatment. ASM-treated seedlings (45 DAS) showed greater reduction of both local and systemic infection by TSWV than older plants (75 DAS), which did not show a significant reduction of TSWV compared with nontreated plants. Our results, along with the previous observations (16), indicate there is a definite age of tobacco for sensitization by ASM. SAR induction in seedlings is crucial because the plant is susceptible to TSWV at this stage and as the plant gets older, mature plant resistance leads to fewer new infections. Information on the ASM-induced SAR would help in determining the optimum time of application of ASM to ensure the highest level of SAR. The challenge inoculation of TSWV every $24 \mathrm{~h}$ after treatment with ASM showed activation of high levels of resistance from 5 days onward as indicated by the drastic reduction of number of local lesions caused by TSWV. This result suggests that 5 to 6 days should be allowed after the ASM treatment for inducing a high level of resistance. The duration of persistence of ASM-induced SAR was not investigated in this study. While the ASM-induced protection seen in field conditions $(16,59)$ was in response to thrips-mediated inoculation under natural conditions, the response of tobacco to TSWV in these studies was evaluated
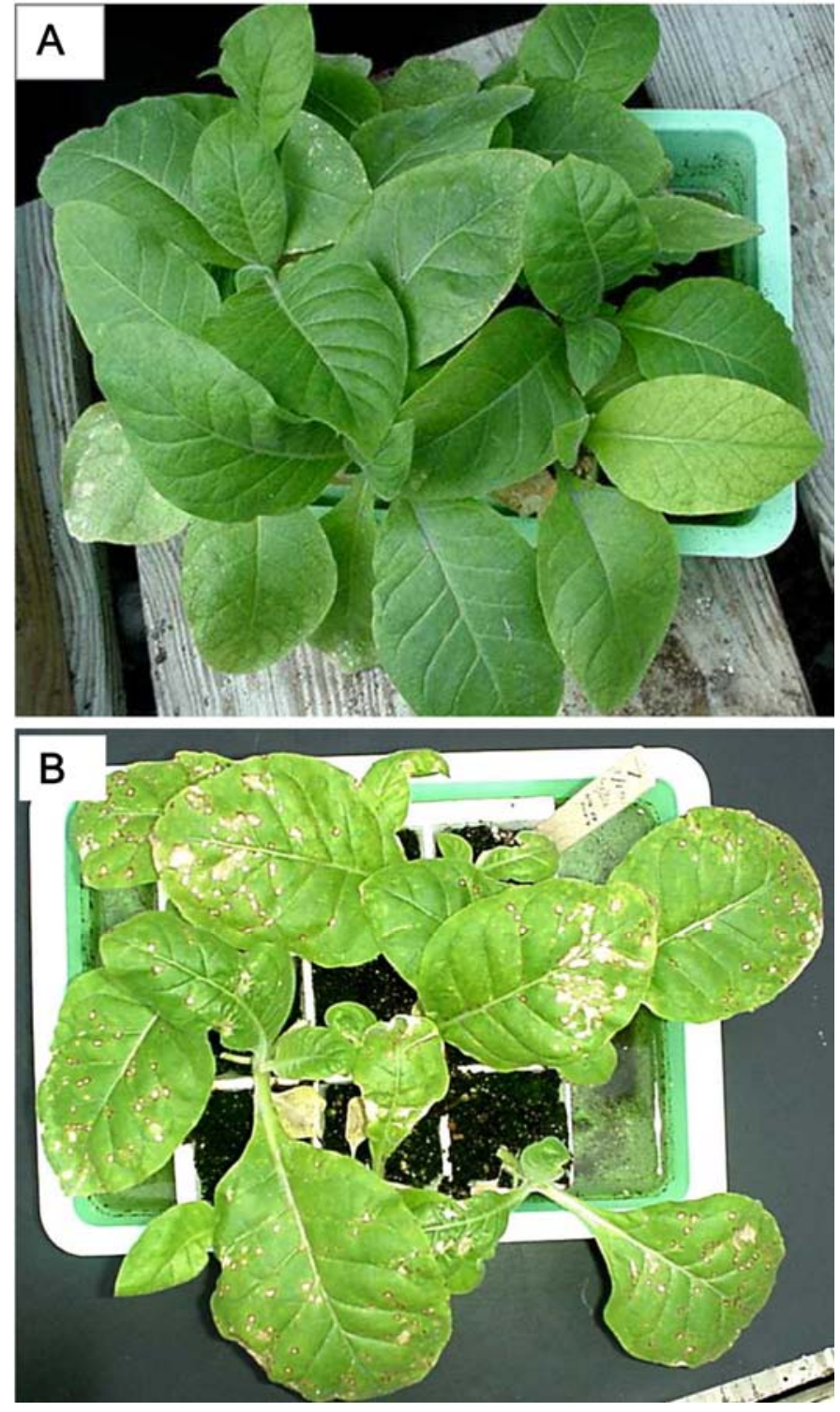

Fig. 6. Protection of tobacco plants of cv. K326 by acibenzolar-S-methyl (ASM) from infection by Tomato spotted wilt virus at 5 days posttreatment. Plants were treated with $\mathbf{A}$, ASM at the rate of $4 \mathrm{~g}$ a.i./7,000 plants or $\mathbf{B}$, water.

based on mechanical inoculations. To minimize the possibility of generating defective interfering RNAs and/or attenuated strains, the number of passages of the original isolate was kept at the minimum.

Imidacloprid was shown to be effective in suppressing spotted wilt in the field $(16,59)$. Challenge inoculation of TSWV to the imidacloprid-treated plants did not result in suppression of local and systemic infection or the ELISA absorbance values. Under field conditions, the suppressive effect of imidacloprid may be due to its insecticidal properties.

Biological or chemical activation of SAR was correlated with systemic accumulation of PR proteins $(31,36,79,81)$. Expression of PR gene and proteins was examined to understand the possible mechanism of action of ASM against TSWV. Total proteins in the ASM-treated plants significantly increased a day after treatment with ASM. Of the several protein bands observed in the ASMtreated plants compared with the nontreated plants, only PR-1, PR-3, and PR-5 were detected, while PR-2, PR-6, and PR-8 were not detected. Accumulation of PR proteins was weak at 1 DPT but a stronger accumulation was observed at 2 DPT. Challenge inoculation of plants at different times after ASM treatment showed 
TABLE 2. Responses of seedlings and older plants treated with acibenzolar-S-methyl (ASM) to Tomato spotted wilt virus ${ }^{\mathrm{y}}$

\begin{tabular}{|c|c|c|c|c|c|c|}
\hline \multirow[b]{3}{*}{ Age of plant ${ }^{2}$} & \multirow[b]{3}{*}{ Treatment } & \multicolumn{3}{|c|}{ Local infection } & \multirow{2}{*}{\multicolumn{2}{|c|}{$\begin{array}{c}\text { Systemic infection } \\
\% \text { Plants }\end{array}$}} \\
\hline & & \multirow[b]{2}{*}{ No. of lesions/plant } & \multicolumn{2}{|c|}{$\%$ Plants } & & \\
\hline & & & Symptomatic & ELISA positive & Symptomatic & ELISA positive \\
\hline \multirow[t]{2}{*}{$\overline{75}$} & Treated & 3.0 & 63.3 & 90.0 & 0.0 & $6.7 \mathrm{a}$ \\
\hline & Nontreated & 20.3 & 100.0 & 100.0 & 0.0 & $13.3 \mathrm{a}$ \\
\hline \multirow[t]{2}{*}{45} & Treated & 0.2 & 10.0 & 60.0 & 3.3 & $6.7 \mathrm{a}$ \\
\hline & Nontreated & 87.6 & 100.0 & 100.0 & 50.0 & $73.3 \mathrm{~b}$ \\
\hline
\end{tabular}

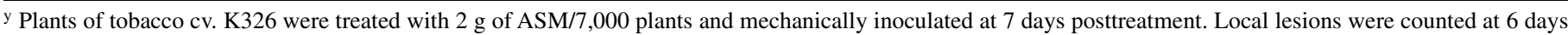
postinoculation (DPI) and systemic infection was judged by testing root samples by enzyme-linked immunosorbent assay (ELISA) at 30 DPI. ASM treatment significantly reduced local and systemic infections compared with nontreated control plants only in plant age 45 days after seeding (DAS) but not in 75 DAS according to the least significant difference test at $P=0.05$. Values in columns marked with same letter are not significantly different at $P=0.05$.

${ }^{z}$ Plants were transplanted to pots 35 DAS.
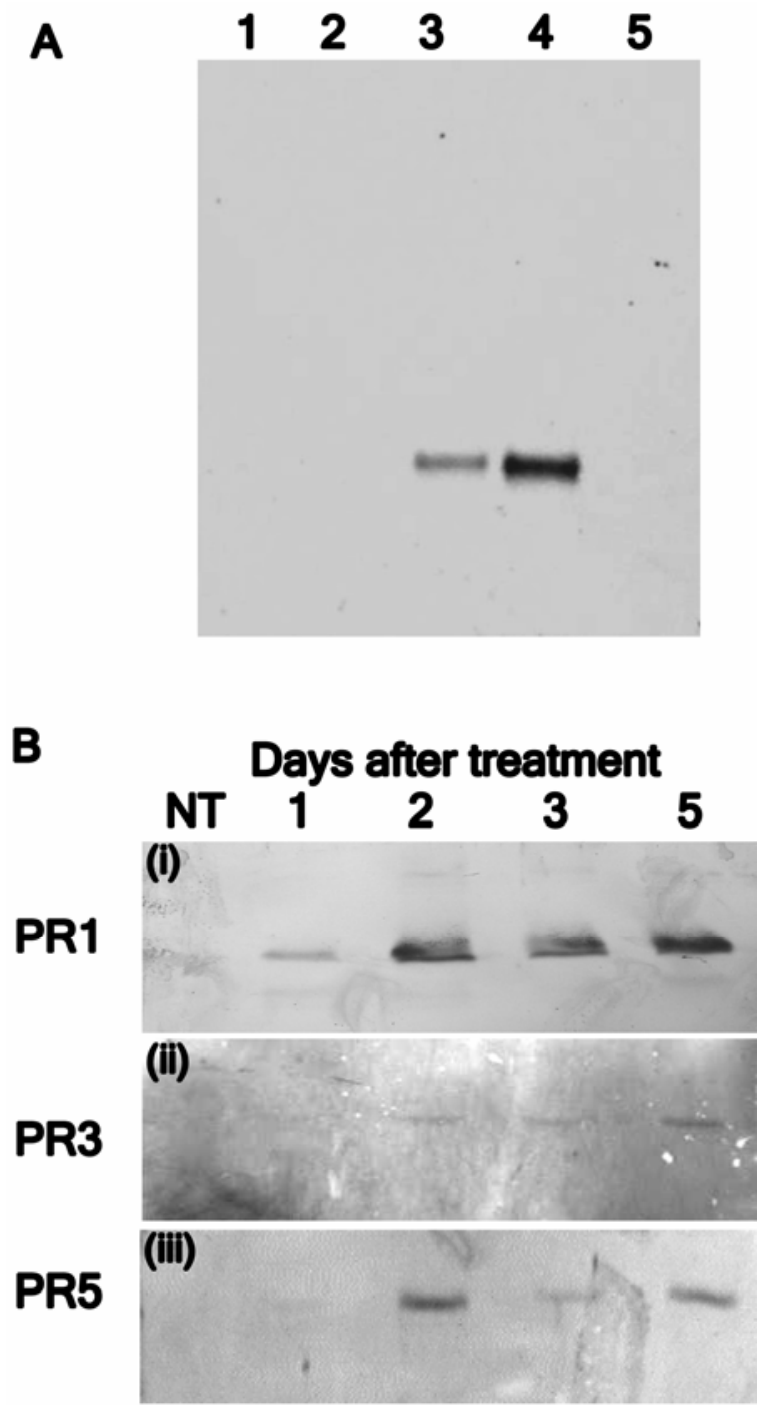

Fig. 7. Accumulation of pathogenesis-related (PR) gene and proteins following treatment with acibenzolar-S-methyl (ASM). A, Northern blot showing systemic expression of mRNA of PR-Q gene. Two months after seeding, tobacco cv. K326 was treated with $2 \mathrm{~g}$ of ASM/7,000 plants and total mRNA was isolated at 15 days posttreatment. Lane 1 , lower leaves from plants treated with water; lane 2, young leaves from the same plants as in lane 1; lane 3, ASM-treated lower leaves; lane 4, young leaves from the same treated plants as in lane 3; and lane 5, cowpea leaves treated with water. The mRNA blot was hybridized with the nonradioactive probe to PR-Q cloned DNA $(1,020$ nucleotides). B, Western blots showing accumulation of PR proteins. Seedlings of tobacco cv. K326 were treated with ASM at the rate of $2 \mathrm{~g} / 7,000$ plants and protein was isolated at 1, 2, 3, and 5 days posttreatment. Antisera used were raised against tobacco PR proteins PR-1 (B, i), PR-3 (B, ii), and PR-5 $(\mathrm{B}$, iii). $\mathrm{NT}=$ nontreated control (protein sample from plants treated with water). reduced number of local lesions caused by TSWV 2 DPT. A correlation between resistance induction and PR protein induction by ASM was observed.

Ziadi et al. (81) used the same antisera, as in the present study, to analyze PR proteins induced by ASM in cabbage. It was reported that PR-2 (glucanase) was rapidly induced but PR-1 and PR-5 were induced slowly and in trace quantity. In our study, PR1 was detected prominently and rapidly but PR-2 could not be detected. PR-3 (chitinase) was not induced by ASM in cabbage (81). However, we observed the expression of PR-Q (PR-3) mRNA and protein in the ASM-treated plants. Wendehenne et al. (78) also showed accumulation of PR-3 mRNA in BTH-treated tobacco. The spectrum of resistance activated and PR proteins induced by ASM are crop specific $(36,56,73)$. We have observed induction of several proteins in the SDS-PAGE gel, but only three PR proteins were detected in western blots. Further investigation would help understand the role of PR proteins in ASM-induced SAR against TSWV in flue-cured tobacco.

This study suggests that there are certain critical factors that influence the efficacy of ASM in inducing SAR against TSWV in flue-cured tobacco: (i) the concentration of ASM should be at least $2 \mathrm{~g}$ a.i/7,000 plants, (ii) seedlings should be treated prior to their transplant in the field since little benefit was seen treating older plants, and (iii) 5 to 6 days should be allowed posttreatment for an effective induction of SAR. These three factors were validated in evaluating seven additional cultivars of flue-cured tobacco, where equally high levels of resistance were achieved by ASM treatment. TSWV continues to be an economic constraint to tobacco production in southern United States and management options are limited. The present and previous work $(16,59)$ suggest that use of ASM to induce SAR could be used as a management strategy for reducing the impact of TSWV in flue-cured tobacco.

\section{ACKNOWLEDGMENTS}

This work was supported in part by funding from Georgia Agricultural Commodity Commission for tobacco and Syngenta Crop Protection, Inc. B. Mandal was supported by a postdoctoral fellowship from USDACSREES Special Grant (99-34412-7415). We thank W. Tillery for technical help and D. Gent and H. Schwartz for their comments on this manuscript. PPNS No. 0468, Department of Plant Pathology, College of Agricultural, Human and Natural Resource Sciences, Project WNPO 0545, Washington State University, Pullman 99164-6430.

\section{LITERATURE CITED}

1. Abbasi, P. A., Al-Dahmani, J., Sahin, F., Hoitink, H. A. J., and Miller, S. A. 2002. Effect of compost amendments on disease severity and yield of tomato in conventional and organic production system. Plant Dis. 86:156161.

2. Alexander, D., Goodman, R. M., Gut-Rella, M., Glascock, C., Weymann, K., Friedrich, L., Maddox, D., Ahl-Goy, P., Luntz, T., Ward, E., and Ryals, J. 1993. Increased tolerance to two oomycete pathogens in transgenic 
tobacco expressing pathogenesis related protein 1a. Proc. Natl. Acad. Sci. USA 90:7327-7331.

3. Anfoka, G. H. 2000. Benzo-(1,2,3)-thiadiazole-7-carbothioic acid Smethyl ester induces systemic resistance in tomato (Lycopersicon esculentum. Mill cv. Vollendung) to Cucumber mosaic virus. Crop Prot. 19:401-405.

4. Babu, R. M., Sajeena, A., Vijayasamundeeswari, A., Sreedhar, A., Vidhyasekeran, P., and Reddy, M. S. 2003. Induction of bacterial blight (Xanthomonas oryzae pv. oryzae) resistance in rice by treatment with acibenzolar-S-methyl. Ann. Appl. Biol. 143:333-340.

5. Beauverie, J. 1901. Essais d'immunisation des végétaux contre les maladies cryptogamiques. CR Acad. Sci. Paris 133:107-110.

6. Benhamou, N., and Belanger, R. R. 1999. Induction of systemic resistance to Pythium damping off in cucumber plants by benzothiadizole: Ultrastructure and cytochemistry of the host response. Plant J. 14:13-21.

7. Bokshi, A. I., Morris, S. C., and Deverall, B. J. 2003. Effects of benzothiadiazole and acetylsalicylic acid on $\beta$-1,3-glucanase activity and disease resistance in potato. Plant Pathol. 52: 22-27.

8. Brissct, M. N., Cesborn, S., Thomson, S. V., and Paulin, J. P. 2000. Acibenzolar-S-methyl induces the accumulation of defense-related enzymes in apple and protects from fire blight. Eur. J. Plant Pathol. 106:529-536.

9. Buonaurio, R., Scarponi, L., Ferrara, M., Sidoti, P., and Bertona, A. 2002. Induction of systemic acquired resistance in pepper plants by acibenzolarS-methyl against bacterial spot disease. Eur. J. Plant Pathol.108:41-49.

10. Campbell, H., and Wilson, M. 1999. Evaluation of Actigard (CGA245704) for the control of bacterial spot of peach. (Abstr.) Phytopathology 89(suppl.):S11.

11. Chester, K. S.1933. The problem of acquired physiological immunity in plants. Quat. Rev. Biol. 8:275-324.

12. Choe, J. J., Custer, D. M., Brommonschenkel, S. H., and Tanksley, S. D. 1996. Conventional breeding: Host-plant resistance and the use of molecular markers to develop resistance to tomato spotted wilt virus. Acta Hortic. 431:367-378.

13. Cohen, Y. 2001. The BABA story of induced resistance. Phytoparasitica 29:375-378.

14. Cole, D. L. 1999. The efficacy of acibenzolar-S-methyl, an inducer of systemic acquired resistance, against bacterial and fungal diseases of tobacco. Crop Prot. 18:267-273.

15. Colson-Hanks, E. S., Allen, S. J., and Deverall, B. J. 2000. Effect of 2,6dichloroisonicotinic acid or benzothiadiazole on Alternaria leaf spot, bacterial blight and Verticillium wilt in cotton under field conditions. Austr. Plant Pathol. 29:170-177.

16. Csinos, A. S., Pappu, H. R., McPherson, R. M., and Stephenson, M. G. 2001. Management of Tomato spotted wilt virus in flue-cured tobacco with acibenzolar-S-methyl and imidacloprid. Plant Dis. 85:292-296.

17. Culbreath, A. K., Csinos, A. S., Bertrand, P. F., and Demski, J. W. 1991. Tomato spotted wilt virus epidemic in flue-cured tobacco in Georgia. Plant Dis. 75:483-485.

18. Edreva, A. 2004. A novel strategy for plant protection: Induced resistance. J. Cell Mol. Biol. 3:61-69.

19. Elliot, R. M. 1996. Pages 295-332 in: The Bunyaviridae: Concluding Remarks and Future Prospects. R. M. Elliot, ed. Plenum Press, New York.

20. Friedrich, L., Lawton, K., Ruess, W., Masner, P., Specker, N., Rella, M. G., Meier, B., Dincher, S., Staub, T., Uknes, S., Métraux, J. P., Kessmann, H., and Ryals, J. A. 1996. Benzothiadiazole derivative induces systemic acquired resistance in tobacco. Plant J. 10:61-70.

21. Gent, D. H., and Schwartz, H. F. 2005. Management of Xanthomonas leaf blight of onion with a plant activator, biological control agents, and copper bactericides. Plant Dis. 89:631-639.

22. Görlach, J., Volrath, S., Knauf Beiter, G., Hengy, G., Beckhove, U., Kogel, K. H., Oostendorp, M., Staub, T., Ward, E., Kessman, H., and Ryals, J. 1996. Benzothiadiazole, a novel class of inducers of systemic acquired resistance, activates gene expression and disease resistance in wheat. Plant Cell. 8:629-643.

23. Gottstein, H. D., and Kuc, J. 1989. Induction of systemic resistance to anthracnose in cucumber by phosphates. Phytopathology 79:176-79.

24. Gozzo, F. 2003. Systemic resistance in crop protection: From nature to a chemical approach. J. Agric. Food. Chem. 51:4487-4503.

25. Graves, A. S., and Alexander, S. A. 2002. Managing bacterial speck and spot of tomato with acibenzolar-S-methyl in Virginia. Plant Health Progress doi:10.1094/PHP-2002-0220-01-RS

26. Hobbs, H. A., Black, L. L., Johnson, R. R., and Valverde, R. A. 1994. Difference in reactions among tomato spotted wilt virus isolates to three resistant Capsicum chinense lines. Plant Dis. 78:1220

27. Hoffmann, K., Qiu, W. P., and Moyer, J. W. 2001. Overcoming host- and pathogen-mediated resistance in tomato and tobacco maps to the M RNA of tomato spotted wilt virus. Mol. Plant-Microbe Interact. 14:242-249.

28. Ishii, H., Tomita, Y., Horio, T., Narusaka, Y., Nakazawa, Y., Nishimura, K., and Iwamoto, S. 1999. Induced resistance of acibenzolar-S-methyl
(CGA-245704) to cucumber and Japanese pear diseases. Eur. J. Plant Pathol. 105:77-85.

29. Jensen, B. D., Latunde-Dada, O., Hudson, D., and Lucas, J. A. 1998. Protection of brassica seedlings against downy mildew and damping off by seed treatment with CGA-245704 an activator of systemic acquired resistance. Pestic. Sci. 52:63-69.

30. Jung, J. L., Maurel, S., Fritug, B., and Hahne, G. 1995. Different pathogenesis -related proteins are expressed in sunflower (Helianthus аппии $\mathrm{L}$.) In response to physical, chemical and stress factors. J. Plant Physiol. 154:153-160.

31. Kessmann, H., Staub, T., Hofmann, C., Maetzke, T., Herzog, J., Ward, E., Uknes, S., and Ryals, J. 1994. Induction of systemic acquired resistance in plants by chemicals. Annu. Rev. Phytopathol. 32:439-459.

32. Kuc, J. 2001. Concepts and direction of induced systemic resistance in plants and its application. Eur. J. Plant Pathol. 107:7-12.

33. Kunz, W., Schurter, R., and Maetzke, T. 1997. The chemistry of benzothiadiazole plant activators. Pestic. Sci. 50:275-282.

34. Laemmli, U. K. 1970. Cleavage of structural proteins during the assembly of the head of bacteriophage T4. Nature 227:680-685.

35. Latham, L. J., and Jones, R. A. C. 1998. Selection of resistance breaking strains of tomato spotted wilt tospovirus. Ann. Appl. Biol. 133:385-402

36. Lawton, K. A., Friedrich, L., Hunt, M., Weyman, K., Delaney, T. P., Kessmann, H., Staub, T., and Ryals, J. 1996. Benzothiadizole includes disease resistance in Arabidopsis by activation of the systemic acquired resistance signal transduction pathway. Plant J. 10:71-82.

37. Lee, J., Fry, J., and Tisserat, N. 2003. Dollar spot in four bent grass cultivars as affected by acibenzolar-S-methyl and organic fertilizer. Plant Health Progress doi:10.1094/PHP-2003-0626-01-RS.

38. Leskovar, D. I., and Kolenda, K. 2002. Strobilurin+acibenzolar-S-methyl controls white rust without inducing leaf chlorosis in spinach. Ann. Appl. Biol. 140:171-175.

39. Liu, O., Raghothama, K. G., Hasegawa, P. M., and Bressan, R. A. 1994. Osmotin over expression in potato delays development of disease symptoms. Proc. Natl. Acad. Sci. USA 91:1888-1892.

40. Logemann, J., Melchers, L. S., Tigelaar, H., Sela-Buurlage, M. B., Ponstein, A. S., van Roekel, J. S. C., Bres-Vloemans, S. A., Dekker, I., Cornelissen, B. J. C., vanden Elzen, P. J. M., and Jongedijk, E. 1994. Synergistic activity of chitinases and $\beta-1,3$ glucanases enhances Fusarium resistance in transgenic tomato plants. J. Cell Biochem. 18A:88.

41. Lucas, J. A. 1999. Plant immunization: From myth to SAR. Pestic. Sci. 55:193-196.

42. Lyon, G. D., Reglinski, T., and Newton, A. C. 1995. Novel disease control compounds: The potential to "immunize" plants against infection. Plant Pathol. 44:407-427.

43. Mandal, B., Pappu, H. R., Csinos, A. S., and Culbreath, A. K. 2006. Response of peanut, pepper, tobacco, and tomato cultivars to two biologically distinct isolates of Tomato spotted wilt virus. Plant Dis. 90:11501155.

44. Matheron, M. E., and Porchas, M. 2002. Suppression of Phytophthora root and crown rot on pepper plants treated with acibenzolar-S-methyl. Plant Dis. 86:292-297.

45. Maxson-Stein, K., He, S.-Y., Hammerschmidt, R., and Jones, A. L. 2002. Effect of treating apple trees with acibenzolar-S-methyl on fire blight and expression of pathogenesis-related protein genes. Plant Dis. 86:785-790.

46. McPherson, R. M., Beshear, R. J., and Culbreath, A. K. 1992. Seasonal abundance of thrips (Thysanoptera: Suborders Terebrantia and Tubulifera) in Georgia flue-cured tobacco and impact of management practices on the incidence of tomato spotted wilt virus. J. Entomol. Sci. 27:257-268

47. McPherson, R. M., Pappu, H. R., and Jones, D. C. 1999. Occurrence of five thrips species on flue-cured tobacco and impact on spotted wilt disease incidence in Georgia. Plant Dis. 83:765-767.

48. Melton, T. A., Spivey, B., Broadwell, A., and Wilson, J. 2003. Effects of Actigard phytotoxicity on yield of flue-cured tobacco, Duplin county, 2002. B\&C Tests 18:F021.

49. Metraux, J. P., Ahl-Goy, P., Staub, T., Speich, J., Steinmann, A., Ryals, J., and Ward, E. 1991. Induced systemic resistance in cucumber in response to 2,6-dichloro-isonicotinic acid and pathogens. Pages 432-439 in: Advances in Molecular Genetics of Plant-Microbe Interactions. $\mathrm{H}$. Hennecke and D. P. S. Verma, eds. Kluwer Academic Publisher, Dordrecht, the Netherlands.

50. Momol, M. T., Olson, S. M., Funderburk, J. E., Stavisky, J., and Marois, J. J. 2004. Integrated management of tomato spotted wilt on field-grown tomatoes. Plant Dis. 88:882-890.

51. Morris, S. W., Vernooij, B., Titatarn, S., Starrett, M., Thomas, S., Wiltse, C. C., Frederiksen, R. A., Bhandhufalck, A., Hulbert, S., and Uknes, S. 1998. Induced resistance responses in maize. Mol. Plant-Microbe Interact. 11:643-658.

52. Moury, B., Palloix, A., Selassie, K. G., and Marchoux, G. 1997. Hypersensitive resistance to tomato spotted wilt virus in three Capsicum chinense accessions is controlled by single gene and overcome by virulent 
strains. Euphytica 94:45-52.

53. Moyer, J. W. 1999. Topsoviruses (Bunyaviridae). Pages 1803-1807 in: Encyclopedia of Virology. A. Granoff and R. G. Webster, eds. Academic Press, San Diego, CA.

54. Mumford, R. A., Barker, I., and Wood, K. R. 1996. The biology of the tospoviruses. Ann. Appl. Biol. 128:159-183.

55. Novartis Crop Protection. 1999. Actigard, a new and novel plant health product for protection against diseases of agronomic, vegetable and tree crops. Novartis Crop Protection Tech. Bull. 4.

56. Oostendorp, M., Kunz, W., Dietrich, B., and Staub, T. 2001. Induced disease resistance in plants by chemicals. Eur. J. Plant Pathol. 107:19-28.

57. Pappu, H., Pappu, S., Jain, R., Bertrand, P., Culbreath, A. K., McPherson, R., and Csinos, A. 1998. Sequence characteristics of natural populations of tomato spotted wilt Tospovirus infecting flue-cured tobacco in Georgia. Virus Genes 17:169-177.

58. Pappu, H. R. Tomato spotted wilt virus (Bunyaviridae). In: Encyclopedia of Virology. 3rd ed. B. Mahy and M. van Regenmortel, eds. Elsevier Ltd., Oxford, UK. (In press.)

59. Pappu, H. R., Csinos, A. S., McPherson, R. M., Jones, D. C., and Stephenson, M. G. 2000. Effect of acibenzolar-S-methyl and imidacloprid on suppression of tomato spotted wilt Tospovirus in flue-cured tobacco. Crop Prot. 19:349-354.

60. Pearce, M. J. 2005. 2004 Georgia plant disease loss estimates. University of Georgia Cooperative Extension Service. Published online by the Univ. Georgia College Agric. Environ. Sci./U.S. Dep. Agric. Special Bull. 41-07.

61. Perez, L., Rodriguez, M. E., Rodriguez, F., and Roson, C. 2003. Efficacy of acibenzolar-S-methyl, an inducer of systemic acquired resistance against tobacco blue mould caused by Peronospora hyoscyami f. sp. tabacina. Crop Prot. 22:405-413.

62. Peters, D. 1998. An updated list of plant species susceptible to tospoviruses. Pages 107-110 in: Recent Progress in Tospovirus and Thrips Research. D. Peters and R. Goldbach, eds. Fourth Int. Symp. on Tospoviruses and Thrips on Floral and Vegetable Crops, Wageningen.

63. Qiu, W. P., Geske, S. M., Hickey, C. M., and Moyer, J. W. 1998. Tomato spotted wilt Tospovirus genome reassortment and genome-specific adaptation. Virology 244:186-194.

64. Ray, J. 1901. Les maladies cryptogamiques des végétaux. Rev. Gen. Bot. 13:145-151.

65. Romero, A. M., Kousik, C. S., and Ritchie, D. F. 2001. Resistance to bacterial spot in bell pepper induced by acibenzolar-S-methyl. Plant Dis. 85:189-194.

66. Ross, A. F. 1961. Systemic acquired resistance induced by localized virus infection in plants. Virology 14:340-358.

67. Ruess, W., Mueller, K., Kanuf-Beiter, G., Kunz, W., and Staub, T. 1996. Plant activator (CGA-245704): an innovative approach for disease control in cereals and tobacco. Pages 53-60 in: Proc. Brighton Crop Prot. Conf.
Pest and Dis. British Crop Protection Council.

68. Ryals, J., Lawton, K. A., Delaney, T. P., Friedrich, L., Kessman, H., Neuenschwander, U., Uknes, S., Vernooij, B., and Weymann, K. 1995. Signal transduction in systemic acquired resistance. Proc. Natl. Acad. Sci. USA 92:4202-4205.

69. Ryals, J., Uknes, C., and Ward, E. 1994. Systemic acquired resistance. Plant Physiol. 104:1109-1112.

70. Sambrook, J., Fritsch, E. F., and Maniatis, T. 1989. Molecular Cloning: A Laboratory Manual. 2nd ed. Cold Spring Harbor Laboratory, Cold Spring Harbor, NY.

71. Sherwood, J. L., German, T. L., Moyer, J. W., Ullman, D. E., and Whitfield, A. E. 2000. Tomato spotted wilt. Pages 1030-1031 in: Encyclopedia of Plant Pathology. O. C. Maloy and T. D. Murray, eds. John Wiley \& Sons, New York.

72. Sticher, L., Mauch-Mani, B., and Metraux, J. P. 1997. Systemic acquired resistance. Annu. Rev. Phytopathol. 35:235-270.

73. Tally, A., Oostendorp, M., Lawton, K., Stub, T., and Bassi, B. 1999. Commercial development of elicitors of induced resistance to pathogens. Pages 357-369 in: Induced Plant Defenses Against Pathogens and Herbivores. A. A. Agrawal, S. Tuzun, and E. Bent, eds. The American Phytopathological Society, St. Paul, MN.

74. Ullman, D. E., Sherwood, J. L., and German, T. L. 1997. Thrips as vectors of plant pathogens. Pages 539-565 in: Thrips as Crop Pests. T. Lewis, ed. CAB International, Wallingford, UK.

75. Vallad, G. E., and Goodman, M. 2004. Systemic acquired resistance and induced systemic resistance in conventional agriculture. Crop Sci. 44:1920-1934.

76. Van Wees, S. C. M., de Swart, E. A. M., van Pelt, J. A., van Loon, L. C., and Pieterse, M. J. 2000. Enhancement of induced disease resistance by simultaneous activation of salicylate- and jasmonate-defense pathways in Arabidopsis thaliana. Proc. Natl. Acad. Sci. USA 97:8711-8716.

77. Ward, E. R., Uknes, S. J., Williams, S. C., Dincher, S. S., Wiederhold, D. L., Alexander, D. C., Ahl-Goy, P., Métraux, J. P., and Ryals, J. A. 1991. Coordinated gene activity in response to agents that induce systemic acquired resistance. Plant Cell 3:1085-1094.

78. Wendehenne, D., Durner, J., Chien, Z., and Klessig, D. F. 1998. Benzothiadiazole, an inducer of plant defenses, inhibits catalase and ascorbate peroxidase. Phytochemistry 47:651-657.

79. White, R. F. 1979. Acetylsalicylic acid (aspirin) induces resistance to tobacco mosaic virus in tobacco. Virology 99:410-412.

80. Whitfield, A. E., Ullman, D. E., and German, T. L. 2005. Tospovirusthrips interactions. Annu. Rev. Phytopathol. 43:459-489.

81. Ziadi, S., Barbedette, S., Godard, J. F., Monot, C., Corre, D. L., and Silue, D. 2001. Production of pathogenesis related proteins in the cauliflower (Brassica oleracea var. botrytis)-downy mildew (Perenospora parasitica) pathosystem treated with acibenzolar-S-methyl. Plant Pathol. 50:579-586. 